OnLine Journal of Earth Sciences 13 (1): 1-9, 2019

ISSN: 1991-7708

(C) Medwell Journals, 2019

\title{
The Field and Petrographic Studies of the Sara-Fier Granite Suite, Central Nigeria
}

\author{
${ }^{1}$ T. Aga and ${ }^{2}$ A.I. Haruna \\ ${ }^{1}$ Department of Geology, University of Jos, Jos, Nigeria \\ ${ }^{2}$ Department of Applied Geology, Abubakar Tafawa Balewa University, Bauchi, Nigeria
}

\begin{abstract}
The Sara-Fier granite suite is one of the several anorogenic younger granite complexes that is located approximately $120 \mathrm{~km}$ South East of Jos, Nigeria. The complex is found to comprise of felsic rocks like; biotitegranites, biotite microgranites, hornblende biotite granites, pyroxene fayalite granites and syenite. They are also found to be associated with mafic rocks like gabbroic diorites and diorites which at some portions have formed hybrid rocks. The complex intruded the basement rocks of central Nigeria. Structural trends on these rocks suggest that they were controlled by some deep seated structures of the basement. Mineral suite identified include; fayalite, pyroxene, amphibole, k-feldspar, biotite, quartz, iron-oxide and accessory minerals like zircon, apatite and allanite. Generally, the petrography of these rock samples reveal the presence of a mafic magma which has two pulses (a mafic and felsic pulse) of injection.
\end{abstract}

Key words: Sara-Fier, granite, geology, petrography, structures, quartz

\section{INTRODUCTION}

The younger granites ring complexes are located in the Southern part of a $200 \mathrm{~km}$ wide zone, along the 9th meridian and extending 1,250 km from Andrar Bous in Northern Niger to Afu in the margin of the Benue trough in Nigeria (Fig. 1). The form and general pattern of the ring centres may have been controlled by pre-existing lines of weakness in the Pan African basement (Kinnaird, 1985).

The Sara-Fier younger granite complex is one of the several anorogenic alkaline younger granite complexes in the Nigerian Pan African basement complex (Macleod et al., 1971) (Fig. 1 and 2). The complex is found associated with dioritic enclaves, peralkaline and peraluminous igneous rocks (Plates 1).

In the study of the Nigerian younger granites, the Sara-Fier complex constitute a significant window to the detailed understanding of the magmatic evolutionary trends and metallogenic characteristics of the Nigerian younger granites as a whole. This is because of the occurrence of diorites which may represent the more primitive magma in the younger granite province. At present, the origin of these anorogenic granites in Nigeria is still very intriguing due to inadequate data. This study attempts to describe the various lithological units within the suite and the petrographic analysis.

Study area: The area investigated is the Sara-Fier younger granite complex which can be accessed through Pankshin town. Pankshin lies approximately $120 \mathrm{~km}$ South East of Jos, Plateau state. The complex is situated between latitudes $09^{\circ} 14^{\prime} 30^{\prime \prime} \mathrm{N}$ and $09^{\circ} 37^{\prime} 30^{\prime \prime} \mathrm{N}$ and longitudes $09^{\circ} 17^{\prime} 30^{\prime \prime} \mathrm{E}$ and $09^{\circ} 30^{\prime} 00^{\prime \prime} \mathrm{E}$ which belong to part of Pankshin sheet 190 NE. This suite occupies an area of approximately $551.77 \mathrm{~km}^{2}$ and compose almost entirely of intrusive rocks (Fig. 2). Four of the ring structures overlap one another and age relationship can be determined with certainty (Fig. 1).

The area is characterized by highlands and ridges that trend in the NW direction with the highest height about $1,716 \mathrm{~m}$ above sea level in the North. The central part of the study areas is approximately flat with an elevation of approximately $489 \mathrm{~m}$ above sea level. River Fier and its tributaries flow in the North East direction. Generally, the lowlands constitute the basement rocks while the younger granite rocks exhibit high relief due to its resistance to weathering. The river is seasonal, display a dendritic drainage pattern and is morphologically controlled. (Fig. 2 and 3).

Petrology: Table 1 chemical composition of the rocks of the Sara-Fier younger granite complex. The major composition of 36 selected rock samples is given in Table 1 . The results were plotted on the petrological classification plot developed after Middlemost, 1985. The felsic granitoids fell in the granite section (Fig. 4) and are quart-rich granitoids (Fig. 5). The mafics which are made up of diorites and gabbroic diorites plotted in their appropriate polygons (Fig. 4) and the QAPF diagram suggest that the granitoids are rich in alkali feldspars.

Field description: The description given are generated from field observation during the 6 weeks field work in 


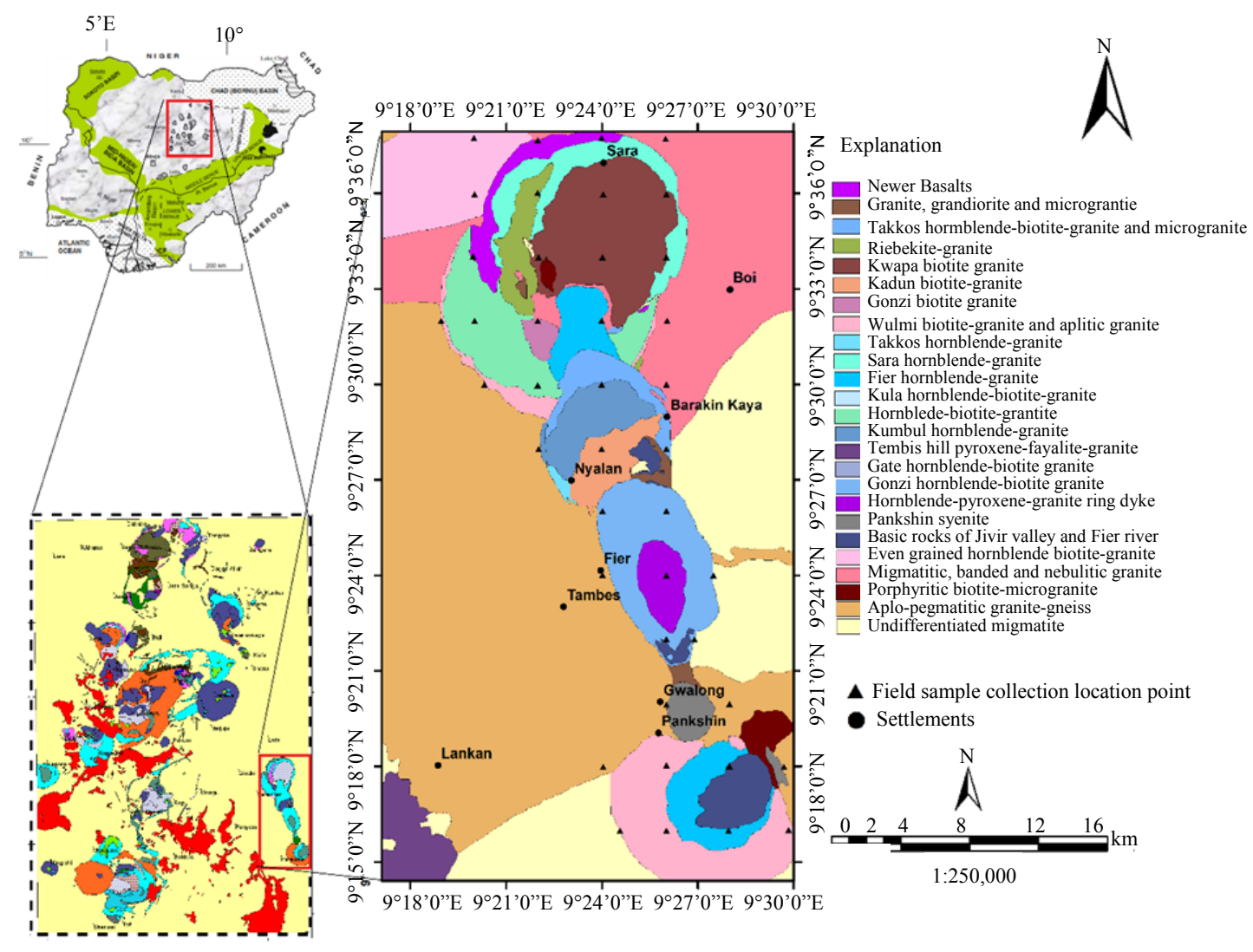

Fig. 1: Top = Geological map of Nigeria showing the location of the younger granite ring complexes (After Obaje, 2009); left map of younger granites ring complexes of Nigeria (Modified after Kinnaird 1985); Centre = geological map of Sara-Fier younger granite complex

the study area. Attention is paid to the colour, texture of the mafics and felsic rocks in the Sara-Fier complex.

Gabbroic diorite/diorite: The gabbroic diorites/diorites are riddled with persistent felsic veins around the Southern portion of the study area. However, a core of small unveined dioritic rock form the larger percentage of the North Western part some of the gabbroic diorites are porphyritic while others are non porphyritic. Brecciated basement rocks occur consisting largely of fragments of the basement rock in a granitic matrix. These are found mainly North of the Fier river within the margin of the main mafic mass. The rock is massive, appear dark gray to dark green in colour. The hybrid diorite is characterized by its distinct and irregular net-veining by the acid phase which is well displaced on some flat slabs to the North of the road outside Duk (Fig. 6).

Hornblende biotite granite: This rock occupies the broad rim of the Fier hills in the northern part and also appear very conspicuous at Takkos, Kula and Gonzi. It weathers to large boulders and form low hills characterized by ungrassed outcrop. The rock is medium to coarse-grained and light in colour. It is essentially made up of feldspar, quartz and mafic minerals (Fig. 7). There are outcrops of hornblende granites at Sara and Kumbul where biotite is very insignificant.

Syenite: The syenite occupies the area between Gwalong and Pank shin. It is a small, stock-like intrusion occupying the Southern part. The rock is medium to coarse grained and green in colour. It is predominately composed of feldspars and hornblende. The syenite intruded the basement rock but the contacts are only well exposed to the East. The famous Pankshin rest house is situated at the peak of this intrusion.

Biotite granite/microgranite: The samples of diorite granites collected from Kwapa, Kadun, Gonzi and Wulmi indicate that they are medium grained in texture and pink 
OnLine J. Earth Sci., 13 (1): 1-9, 2019

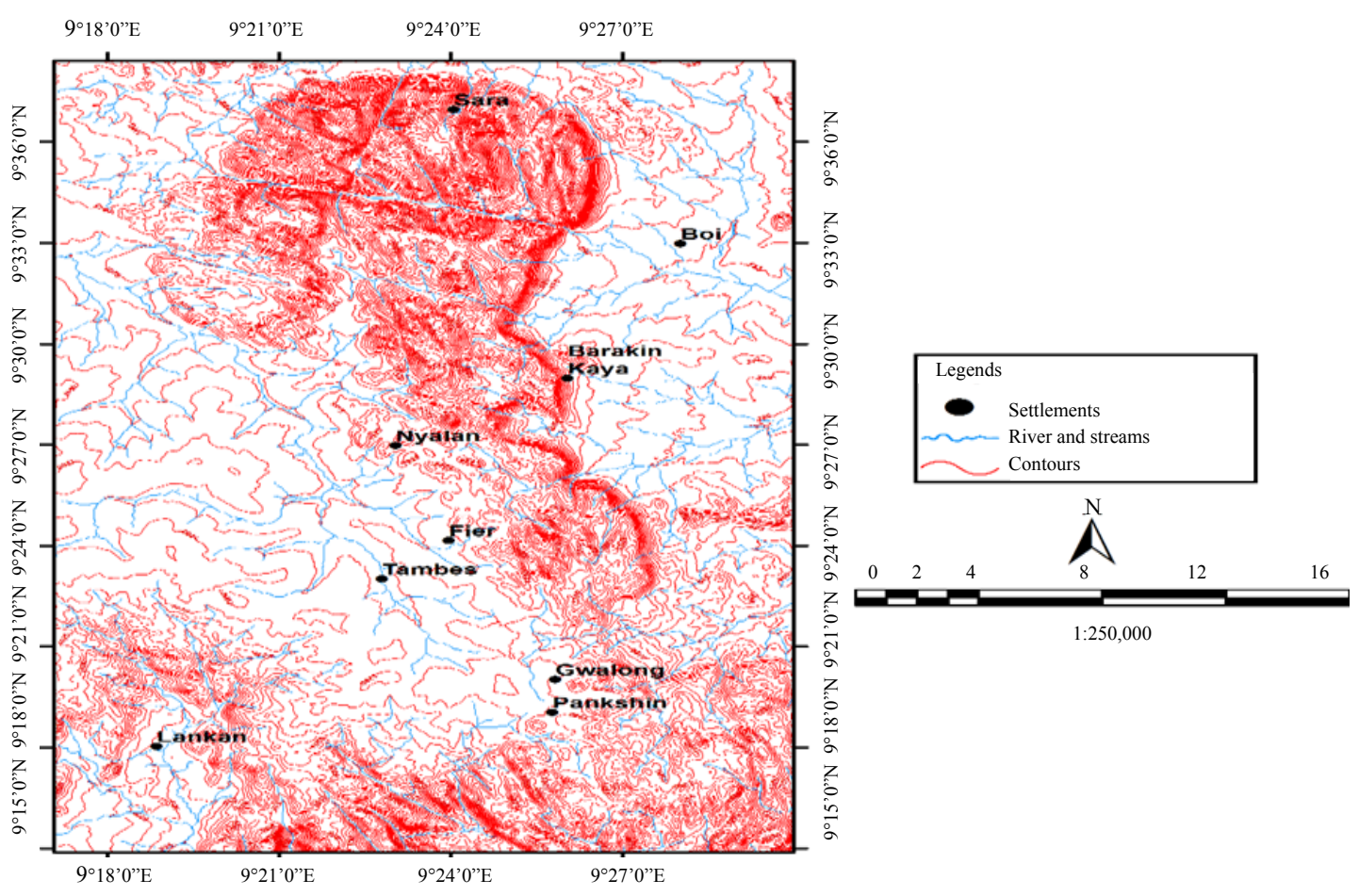

Fig. 2: Physiographic map of the Sara-Fier younger granite complex

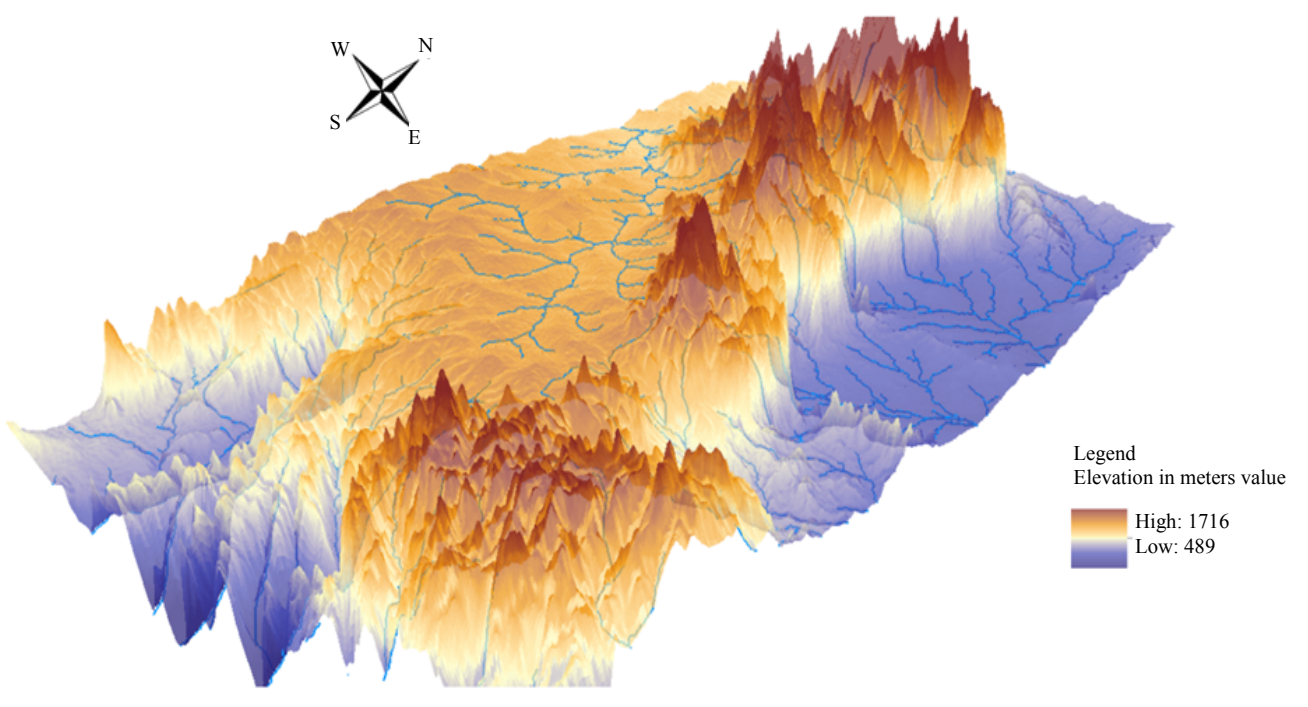

Fig. 3: Digital Elevation Modem (DEM) of the Sara-Fier younger granite complex

in colour. Only the roof zones of the granite is exposed. Biotite microgranite is commonly developed at the contacts with the overlying rocks and zones of greisenization up to 0.7 or $1.0 \mathrm{~m}$ are abundant. The biotite microgranite is a small lenticular intrusion of about $1.4 \mathrm{~km}$. It is emplaced between the hornblende biotite granite and syenite and situated in the central portion of the area of study. It is equigranular in texture and similar to the dark variety of the Kofayi biotite micro granite (Aga and Haruna, 2019a, b).

Pyroxene-fayalite granite/hornblende-fayalite granite: The pyroxene-fatality granite and the hornblende-fayalite granite outcrop at tembes and gate, respectively. The rocks are dark gray with a faint greenish tinge when fresh and turn brownish when weathered. 
OnLine J. Earth Sci., 13 (1): 1-9, 2019

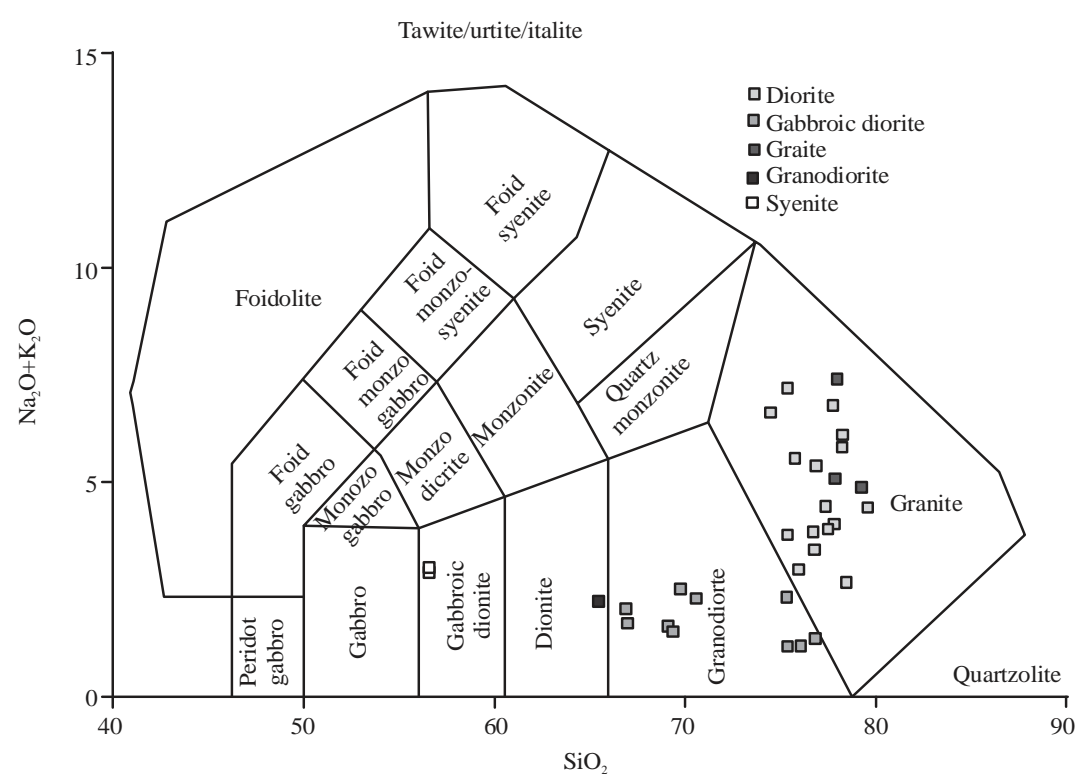

Fig. 4: Rock classification (after Middlemost, 1985)

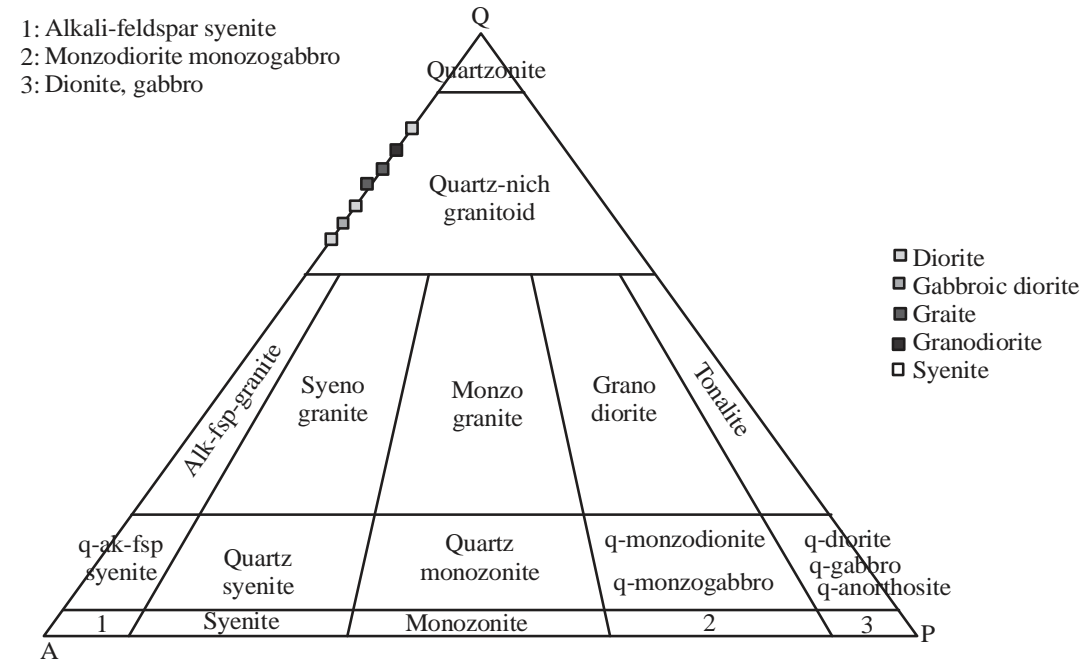

Fig. 5: QAPF-Si oversaturated diagram

\begin{tabular}{|c|c|c|c|c|c|c|c|c|c|c|c|c|c|c|}
\hline Sample ID & Location & Petrology & $\mathrm{SiO}_{2}$ & $\mathrm{CaO}$ & $\mathrm{MgO}$ & $\mathrm{SO}_{3}$ & $\mathrm{~K}_{2} \mathrm{O}$ & $\mathrm{Na}_{2} \mathrm{O}$ & $\mathrm{TiO}_{2}$ & $\mathrm{MnO}$ & $\mathrm{P}_{2} \mathrm{O}_{5}$ & $\mathrm{~F}_{\mathrm{e} 2} \mathrm{O}_{3}$ & $\mathrm{Al}_{2} \mathrm{O}_{3}$ & ${\mathrm{H} 2 \mathrm{O}^{+}}^{+}$ \\
\hline AT2 & Sara-Fier & Granodiorite & 63.10 & 7.05 & 2.060 & 0.460 & 1.03 & 0.840 & 2.120 & 0.260 & 0.000 & 6.040 & 12.04 & 3.24 \\
\hline AT5 & Sara-Fier & Granite & 73.48 & 2.70 & 0.060 & 0.210 & 4.02 & 0.710 & 1.250 & 0.093 & 0.000 & 2.140 & 13.03 & 1.63 \\
\hline AT6 & Sara-Fier & Granite & 74.08 & 1.14 & 0.060 & 0.048 & 5.36 & 1.030 & 0.894 & 0.075 & 0.002 & 1.180 & 13.20 & 2.06 \\
\hline AT9 & Sara-Fier & Granodiorite & 63.10 & 2.37 & 6.340 & 0.000 & 1.46 & 0.240 & 3.110 & 0.300 & 0.000 & 6.250 & 11.20 & 3.51 \\
\hline AT14 & Sara-Fier & Granite & 75.06 & 0.00 & 0.000 & 0.000 & 7.76 & 1.200 & 0.520 & 0.110 & 0.000 & 3.760 & 12.32 & 2.07 \\
\hline AT15 & Sara-Fier & Syenite & 73.00 & 1.96 & 0.800 & 0.000 & 4.40 & 2.400 & 0.230 & 0.170 & 0.003 & 2.250 & 12.01 & 1.96 \\
\hline AT19 & Sara-Fier & Granite & 73.84 & 1.01 & 0.030 & 0.480 & 0.46 & 2.800 & 1.150 & 0.094 & 0.000 & 3.290 & 13.06 & 2.86 \\
\hline AT20 & Sara-Fier & Granodiorite & 64.48 & 4.24 & 3.160 & 0.570 & 2.52 & 0.460 & 2.060 & 0.300 & 0.001 & 6.670 & 11.86 & 3.86 \\
\hline AT24 & Sara-Fier & Granite & 74.40 & 0.94 & 0.030 & 0.430 & 6.40 & 0.740 & 0.071 & 0.040 & 0.000 & 0.400 & 13.62 & 1.03 \\
\hline AT34 & Sara-Fier & Granite & 73.70 & 0.52 & 0.003 & 0.000 & 7.90 & 0.420 & 0.307 & 0.036 & 0.000 & 1.570 & 12.06 & 2.50 \\
\hline AT36 & Sara-Fier & Granite & 74.06 & 1.76 & 0.050 & 0.260 & 4.12 & 0.860 & 0.650 & 0.086 & 0.000 & 1.750 & 13.69 & 1.96 \\
\hline AT40 & Sara-Fier & Granodiorite & 72.89 & 5.37 & 0.440 & 0.640 & 0.64 & 1.020 & 1.500 & 0.080 & 0.020 & 3.080 & 12.00 & 1.60 \\
\hline AT41 & Sara-Fier & Granite & 74.09 & 0.86 & 0.410 & 0.130 & 4.44 & 0.480 & 0.440 & 0.034 & 0.000 & 3.770 & 12.84 & 2.00 \\
\hline AT43 & Sara-Fier & Granodiorite & 59.70 & 4.80 & 3.920 & 0.240 & 2.00 & 0.400 & 2.420 & 0.240 & 0.000 & 7.080 & 12.40 & 6.34 \\
\hline AT46 & Sara-Fier & Granite & 73.04 & 2.04 & 0.430 & 0.240 & 1.03 & 3.320 & 1.780 & 0.110 & 0.001 & 3.390 & 12.10 & 2.46 \\
\hline AT47 & Sara-Fier & Granite & 73.46 & 0.60 & 0.003 & 0.080 & 6.63 & 0.740 & 0.160 & 0.033 & 0.000 & 0.370 & 13.60 & 2.62 \\
\hline AT48 & Sara-Fier & Granite & 72.70 & 1.59 & 0.080 & 0.600 & 3.21 & 0.460 & 2.180 & 0.140 & 0.020 & 4.050 & 13.60 & 1.40 \\
\hline AT50 & Sara-Fier & Granodiorite & 65.03 & 4.54 & 3.080 & 0.240 & 2.30 & 0.430 & 1.550 & 0.250 & 0.003 & 6.350 & 11.40 & 3.48 \\
\hline
\end{tabular}


OnLine J. Earth Sci., 13 (1): 1-9, 2019

\begin{tabular}{|c|c|c|c|c|c|c|c|c|c|c|c|c|c|c|}
\hline$\overline{\text { AT52 }}$ & Sara-Fier & Granite & 73.07 & 0.85 & 0.009 & 0.000 & 4.06 & 1.400 & 0.460 & 0.060 & 0.006 & 2.520 & 14.00 & 1.48 \\
\hline AT55 & Sara-Fier & Granite & 72.10 & 1.49 & 0.230 & 0.210 & 6.20 & 2.060 & 0.570 & 0.130 & 0.000 & 3.760 & 12.43 & 2.08 \\
\hline AT56 & Sara-Fier & Granite & 73.40 & 0.57 & 1.000 & 0.430 & 6.02 & 0.710 & 0.520 & 0.170 & 0.003 & 2.800 & 12.30 & 2.01 \\
\hline AT57 & Sara-Fier & Granodiorite & 72.00 & 2.03 & 0.200 & 0.000 & 2.80 & 0.060 & 3.630 & 0.200 & 0.000 & 5.070 & 11.90 & 1.40 \\
\hline AT58 & Sara-Fier & Diorite & 60.10 & 4.30 & 7.810 & 0.440 & 0.86 & 1.780 & 3.660 & 0.290 & 0.000 & 6.600 & 10.68 & 2.56 \\
\hline AT63 & Sara-Fier & Granodiorite & 72.20 & 5.50 & 1.240 & 0.240 & 1.40 & 0.100 & 2.600 & 0.240 & 0.003 & 2.280 & 12.33 & 2.42 \\
\hline AT64 & Sara-Fier & Granodiorite & 72.06 & 4.03 & 3.220 & 0.000 & 0.42 & 1.040 & 2.030 & 0.180 & 0.001 & 3.100 & 11.03 & 1.84 \\
\hline AT65 & Sara-Fier & Gabbroic diorite & 51.06 & 6.29 & 3.660 & 0.000 & 1.64 & 2.030 & 3.290 & 0.380 & 0.000 & 18.410 & 10.34 & 1.89 \\
\hline AT69 & Sara-Fier & Granite & 75.06 & 0.89 & 0.060 & 0.400 & 4.00 & 1.360 & 0.570 & 0.016 & 0.003 & 1.240 & 12.84 & 2.34 \\
\hline AT73 & Sara-Fier & Granite & 58.00 & 0.28 & 0.030 & 0.000 & 23.30 & 1.060 & 0.620 & 0.130 & 0.000 & 3.010 & 10.62 & 2.48 \\
\hline AT74 & Sara-Fier & Granite & 72.50 & 0.46 & 0.030 & 0.420 & 5.70 & 1.087 & 0.970 & 0.100 & 0.007 & 3.610 & 13.04 & 1.84 \\
\hline AT76 & Sara-Fier & Granite & 73.62 & 0.84 & 0.090 & 0.630 & 6.00 & 0.560 & 0.520 & 0.150 & 0.000 & 2.340 & 13.30 & 1.95 \\
\hline AT77 & Sara-Fier & Granite & 72.00 & 2.00 & 0.240 & 0.000 & 4.00 & 0.710 & 1.240 & 0.250 & 0.000 & 5.010 & 12.24 & 2.10 \\
\hline AT79 & Sara-Fier & Granodiorite & 60.00 & 6.63 & 4.480 & 0.000 & 0.72 & 1.400 & 2.160 & 0.280 & 0.000 & 8.000 & 10.00 & 4.36 \\
\hline AT80 & Sara-Fier & Granite & 74.40 & 31.1 & 0.420 & 0.030 & 5.63 & 0.730 & 0.740 & 0.140 & 0.000 & 1.020 & 13.08 & 1.04 \\
\hline AT82 & Sara-Fier & Granite & 73.40 & 0.84 & 0.260 & 0.002 & 4.80 & 1.040 & 0.150 & 0.071 & 0.024 & 0.580 & 13.06 & 1.01 \\
\hline AT84 & Sara-Fier & Granite & 74.00 & 0.47 & 0.002 & 0.400 & 8.02 & 1.040 & 0.100 & 0.033 & 0.000 & 0.760 & 12.49 & 1.24 \\
\hline AT31 & Sara-Fier & Syenite & 73.48 & 2.04 & 0.400 & 0.440 & 4.40 & 1.320 & 0.900 & 0.120 & 0.000 & 2.110 & 13.36 & 2.12 \\
\hline
\end{tabular}

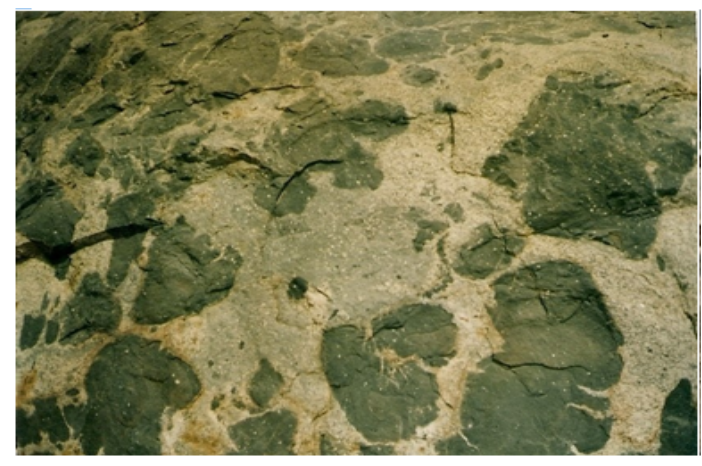

Fig. 6: Dioritic enclaves at duk area

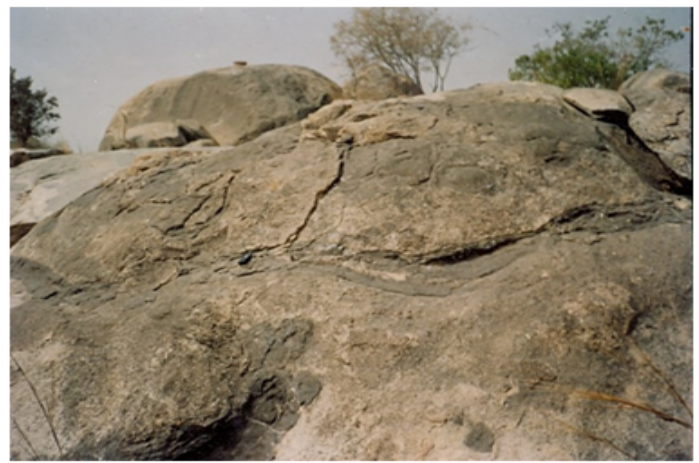

Fig. 7: Hornblende biotite granite

\section{MATERIALS AND METHODS}

Structural geology: The structural features observed in the field of study include joints, dykes, flow structures and veins. Measurement carried out on them reveal that they display variable trends.

Joints: Fractures that are oriented systematically with no evidence of relative movement are called joints. Joints are the commonest occurring feature in the Sara-Fier younger granite complex. The general dominant trend is NNE-SSE (Fig. 8 and 9). Joints observed on the younger granite complex are not structurally controlled

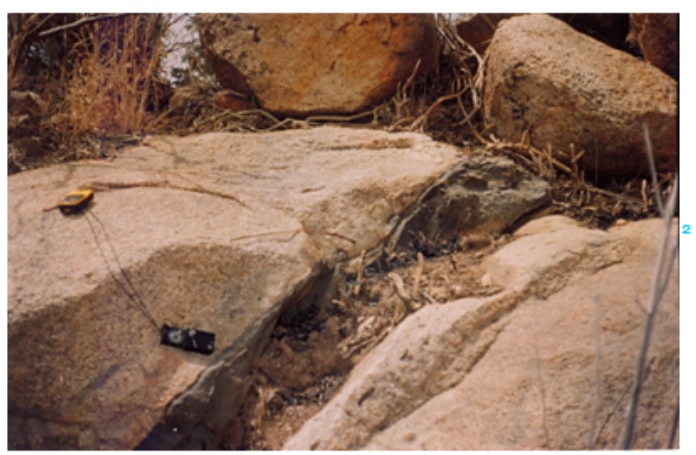

Fig. 8: Dolerite dyke around the Fier

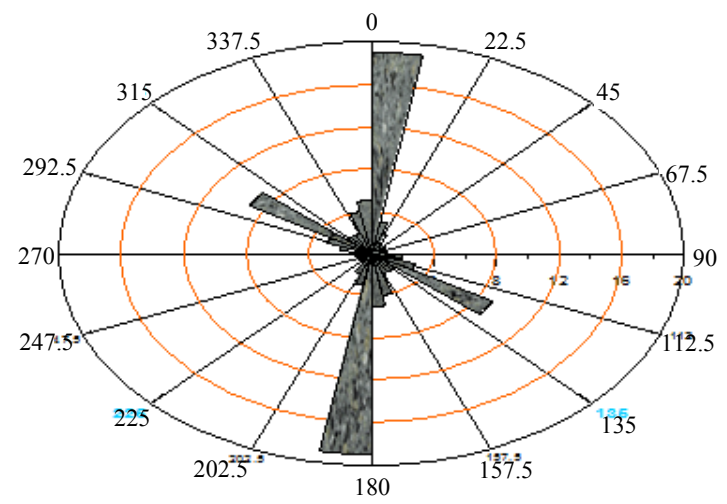

Fig. 9: General structural trend

hence are cooling joints formed as a result of contraction and cooling of the emplaced magma. Also, the uniformity in the trends of the joints suggest that they are syngenetic.

Veins:Veins are joints that have been filled. In the study area, these joints have been filled by quartz and hence are referred to as quartz veins. The quartz veins are mineralized with minerals suspected to be cassiterite or some low quality gems in place, especially, between Dugulun Bauchi and Sara along the Kwapa valley. 
Dykes: A dyke is a sheet-like discordant body within the country rock in which they occur. Most of the dykes are doleritic in composition and located on the syenite and granites. The dolerite dykes at the study area are of variable thickness, ranging from $0.7-2.0 \mathrm{~m}$. They make sharp contacts with the enclosing rocks and are clearly younger than the host rocks. Some of them are discontinuous for about a metre (Plate 8) but entend for several metres.

Net-veins: These are network of veins of felsic intrusions injected under high considerabl pressure and penetrating a marginal zone of the mafic rocks thus forming a meshwork. Felsic magmatic intrusion formed the veining material within the mafic rocks of the Fier and Balang areas. The thickness of the veins vary between 0.3 and $1.0 \mathrm{~m}$.

Xenoliths: A xenolith is a pre-existing rock embedded in a newer (igneous rock). Xenoliths are formed when a rising magma incorporates the pre-existing rock. If the pre-existing rock does not melt, it will not be assimilated into the magma and will therefore, remain distinct from the new igneous rock that surrounds it. Xenoliths observed in the study areas are mostly mafic in composition and of varying sizes, some up to 1.6 by $2.5 \mathrm{~m}$. A larger percentage of the xenoliths are formed in the area of net veinings of mafic rocks by felsic materials.

Structural interpretation: In Nigeria, the major structural direction is oriented NNE-SSE corresponding to one of the major structural trends in the basement complex and direction of alignment of the younger granite ring complexes (Rahaman et al., 1988; Turner 1989).

The form and general distribution pattern of the ring centres may have been controlled by these pre-existing lines of weakness in the Pan-African basement into which the younger granite complexes were intruded. The general structural trend in the study area is shown in Fig. 9. This suggest that these joint direction are outward prolongation of deep seated fracture zones that initiate and guided the location of the younger granite eruption centres. They followed these weak zones during eruption in the Jurassic (165 $\pm 25 \mathrm{~mA})$.

\section{RESULTS AND DISCUSSION}

Petrography: Out of the 52 samples collected from the field, 19 representative samples were presented for thin section. The slides were prepared at the Laboratory of the Department of Geology at the University of Jos, Nigeria. These thin sections which represent the lithological units in the study area were studied under the transmitted light microscope. Particular attention was given to descriptive features such as mineral composition, grain size and inclusions.

Diorite/gabbroic diorite: The diorite and gabbroic diorite look similar in hand specimen.The rock is dense, melanocratic and dark green in colour. It is fine grained and doleritic in texture. The crystals are allotroimorphic, compact and aphanitic which implies that the constituent minerals cannot be distinguished by the unaided eye. The essential minerals are plagioclase, clinopyroxene and biotite.

Under the microscope, the rocks consist mainly of plagioclase groundmass and displays typical doleritic texture. The modal compositions of the gabbroic diorite are shown in Fig. 12. The rock is characterised by an ophitic or sub ophitic groundmass in which intersecting laths of labradorite are enclosed by allotroimorphic pyroxenes (Fig. 10).

Augite crystals are colourless to yellowish brown in colour. Although, they exhibit nice, bright interference colours of the second and third order. They are subhedral in form and show high relief. Most of the crystals have been altered. The plagioclase are subhedral in form, the crystals are colourless and the well-twinned laths are abundantly sericitized and zoned.

Biotite crystals are subhedral in form. Two types of biotite were observed the first, primary biotite is pleochroic from yellowish brown to reddish brown and show high interference colours. The other, secondary biotite is pleochroic from light to dark green and has high interference colours. The secondary biotite is an alteration product. Quartz crystals are colourless and are distinguished by their wavy extinction from light to dark. The crystals are subhedral in form and occur as small interstitial crystals within the groundmass.

Iron oxide occur as dark mineral grains which remain unchanged. They have variable shapes and do not have any definite orientation. Apatite and zircon constitute the accessory minerals present. The former is euhedral to subhedral while the later is subhedral in shape both are colourless syenite.

In hand specimen, the rock is pinkish grey when fresh, speckled with abundant dark clusters and patches of fine-grained hornblende. They resemble those found in the Saiya-Shokobo younger granite complex (Aga and Haruna, 2019a, b). Under the microscope, it has a porphyritic texture with phenocrysts of feldspar distributed in a matrix of perthite, quartz and hornblende (Fig. 11).

Hornblende is pleochroic from pale blue to pale green and it is anhedral in form. The crystals have high birefringence. The main K-feldspar is orthoclase and it occurs in a groundmass of microperthite. It is easily observed due to its sharp extinction from light to dark. Micropethite is partly covered by k-feldspar and does not 
(a)

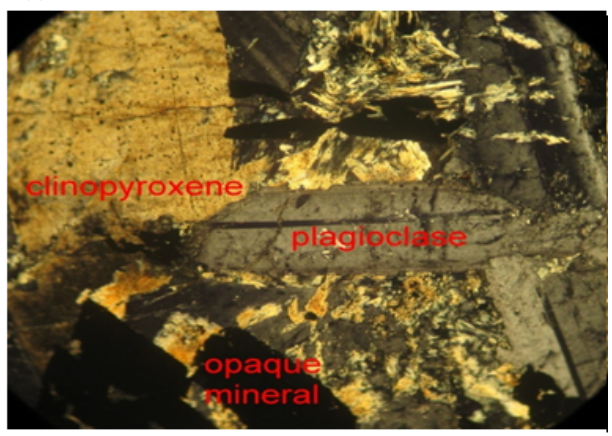

(b)

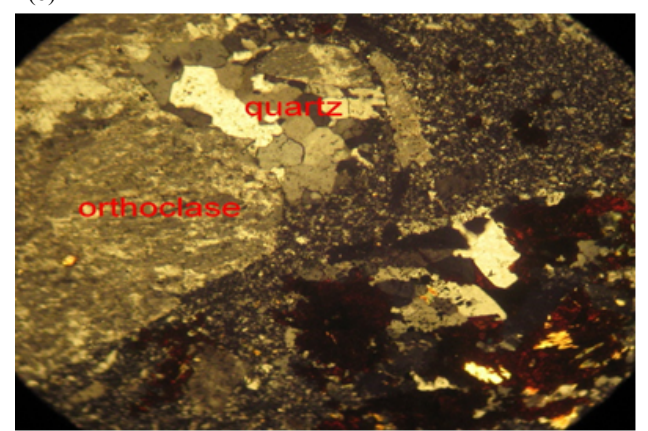

Fig. 10(a, b): Photomicrographs of thin sections of (a) Gabbroic diorite and (b) Syenite

(a)

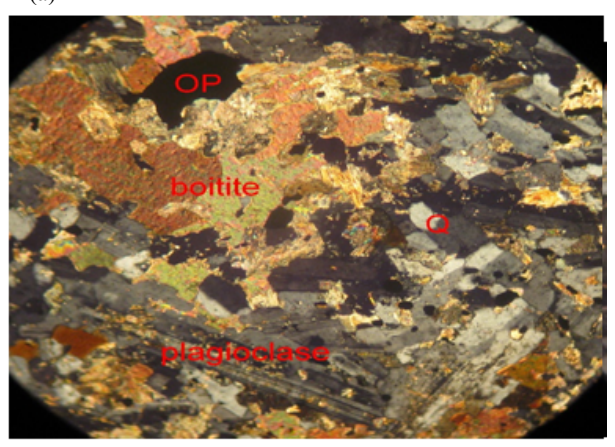

(b)

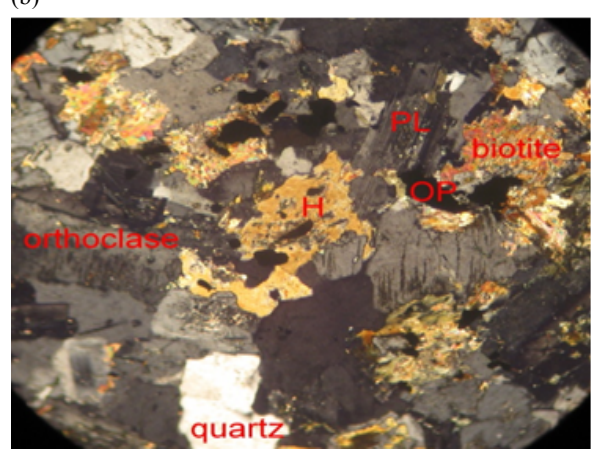

Fig. 11(a, b): Photomicrographs of thin sections of (a) Biotite granite and (b) Hornblende biotite granite
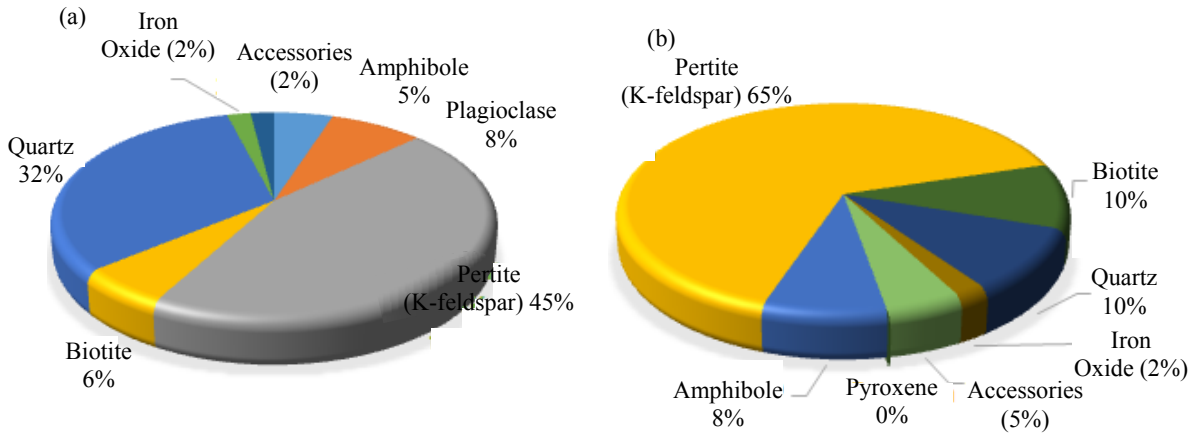

Fig. 12(a, b): Model composition of (a) Gabbroic diorite and (b) Synite

exhibit pleochroism. It also has a muttled appearance. Biotite crystals are subhedral to anhedral in form and occur both as primary and secondary. The primary biotite is pleochroic from greenish brown to dark brown while the secondary biotite (alteration product) is pleochroic from green to light green.

Quartz grains are subhedral in form and each crystal show a high degree of fragmentation. They exhibit wavy extinction and range is size between 0.6 and $0.9 \mathrm{~mm}$ in length. Iron oxide is present and constitute approximately
$1 \%$ of the slide Accessory minerals include zircon and apatite. The estimated modal composition of the rock is given in in form of pie chart (Fig. 12b).

Biotite granite: In hand specimen, the rock varies in colour from pale grey and sometimes pale yellow. It is a granular, medium grained rock and resemble those of the Kofayi younger granite complex (Aga and Haruna, 2019a, b). Under the microscope, the rock is highly weathered and this has resulted in the breakdown of biotite to form 
OnLine J. Earth Sci., 13 (1): 1-9, 2019

(a)

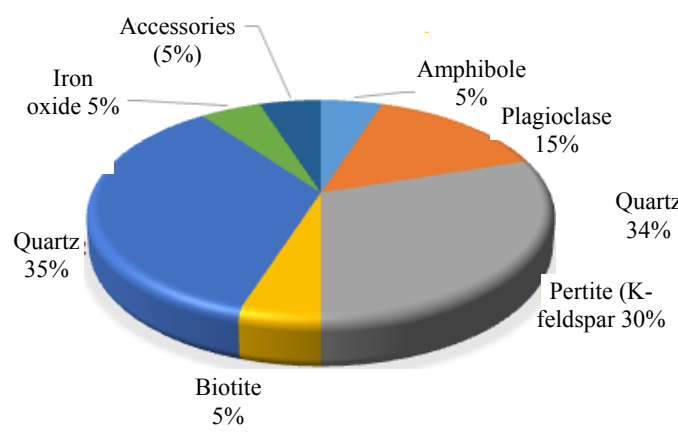

(b)

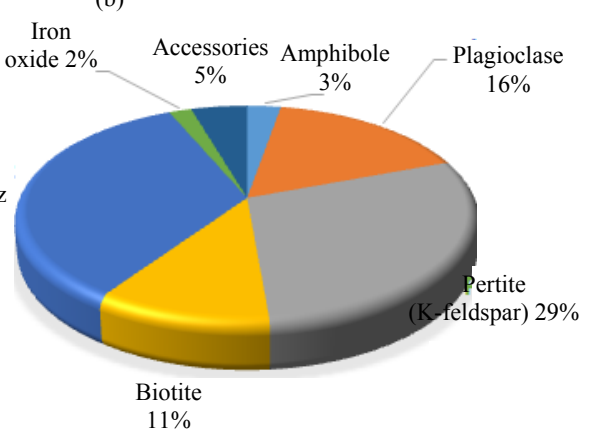

Fig. 13(a, b): Modal composition of (a) Biotite granite and (b) Bioite microgranite

chlorites. The chlorite occurs within the cracks present. The rock has medium to fine grained texture (Fig. 11a).

The feldspar present is actually an irregularly formed perthite. Patches of plagioclase feldspar could be observed on the surface on the K-feldspar. Biotite is pleochroic from pale green to brown and are subhedral in form. The chlorite has light green colouration and occur mainly along the cracks present within the mineral grains. The chlorite has an anhedral crystal form and it occurs as an alteration product. Quartz occurs as euhedral to crystals. Some of the crystals have cracks in them which contain inclusions of a crypto-crystalline material. Iron oxide is less abundant in this sample. It only occurs as tiny black patches in some biotite crystals. The estimated modal composition of the rock is given in form of pie chart (Fig. 13a).

Biotite microgranite: In hand specimen, the rock is fine to medium grained and even-texture. It varies a little in grain size and contains a few basic clots or larger diffuse xenoliths. Minerals present include quartz, K-feldspar (orthoclase), albite, hornblende and accessory minerals. Under the microscope, it consist of irregular crystals of feldspar and quartz. These are distributed as small grains and granophyre intergrowths. Hornblende is present and occur as a primary mineral together with quartz and plagioclase. It is pleochroic from dark to light green and is fractured. It has been replaced by biotite in some places especially in the margins. Oligoclase occur as colourless, subhedral and anhedral crystals. The relief is low with extinction in most crystals parallel to cleavage traces. Others have oblique extinction. Carlsbad twinning is also common.

The K-feldspars are perthite. Plagioclase and microcline are intergrown with quartz. Biotite is pleochroic from light green to dark brown. It penetrates the fractures in plagioclase or associated with quartz aggregates. Quartz occurs as colourless, clear, anhedral and form clusters. It displays undulose extinction. Accessory minerals include allanite, zircon and calcite.
Iron oxides is also present. The estimated modal composition of the rock is given in in form of pie chart (Fig. 13b).

Hornblende-biotite granite: In hand specimen, the rock is dark grey and has equigranular grain size between 0.4-0.9 mm. Under the microscope, quartz and perthite form an interlocking mosaic containing scattered flakes and clusters of mafic minerals, principally hornblende. The hornblende show greenish brown to blue-green pleochroism and is occasionally associated with sheds of biotite. The crystals are subhedral (Fig. 11 right).

Both perthite and separate albite are present and in the former the potash component is cloudy and is veined by albite in a rather irregular way. Biotite which is pleochroic from dark green to straw yellow also occur as net-like crystals replacing the plagioclase member of the perthite. Quartz forms clusters of anhedral grain set between large interlocking crystals of perthite. Iron ore form clusters with the green-brown hornblende as subedral crystals which are sometimes pseudomorphed by biotite. The accessory minerals include fluorite, apatite, zircon and ilmenite.

Riebeckite granite: In hand specimen, the rock is medium-grained and show variation in composition and texture. The quartz and riebeckite grains set in a relatively finer grained matrix that is made up of albite, K-feldspar and quartz. In thin section, the rock contains approximately $15 \%$ albite, $10 \%$ riebeckite, $30 \%$ quartz, $45 \%$ pertite. The main K-feldspar present is orthoclase micropertite with albite occurring as a replacement the orthoclase. The crystals are euhedral to subhedral in form and they occur as phenocrysts within the groundmass. Riebeckite occur as greenish blue crystals with irregular and corroded edges.

Hybrid rock: The contact rock comprise of a slide of gabbroic diorite/granite around Fier and Duk areas. Even in hand-specimen, the contact between the mafic and 
felsic is very sharp. The granitic component is a hornblende-biotite-granite. Under the microscope, the contact is also very visible. Half of it is the coarse-granite and the other half is occupied by the gabbroic diorite. The major component minerals of these granites are microcline, oligoclase, biotite, hornblende and quartz. The accessories include apatite, zircon, allanite, iron ore, epidote, sphene, sericite, muscovite and chlorite.

Petrographic interpretations: Slides of the mafic rocks which comprise of diorites and gabbroic diorites show that plates of plagioclase and hornblende enclose abundant pyroxene, biotite, olivine and iron oxide. This arrangement usually develop during the crystallization of magma formed from ultramafic rocks like peridotite where plates of hornblende surround grains of divine and pyroxenes forming ophitic texture. Most of the biotite and hornblende observed in slides of gabbroic diorites show some level of alteration to iron oxide. This is probably as a result of a subsolidus deuteritic alteration that was brought about by the felsic injection. A general lack of fayalite in the biotite rich granites may likely indicate a low $\mathrm{PO}_{2}$ in the parent magma. Even when the granite became alkaline, the development of aegirine was only sporadic. Within the felsic rocks, biotite microgranites show K-felspar occurring with inclusions of globular quartz. This probably occurred during crystallization or through replacement of one mineral by the other.

\section{CONCLUSION}

The thin section from the hybrid rock show that hornblende biotite and iron oxide occur close to each other. Reaction rims of biotite observed around iron oxide-was probably due to hydrothermal activity that followed the injection of the felsic (granitic) material into the mafic rocks. The heating up of the felsic magma must have resulted to a violent release of volatiles that fractured and brecciated the marginal zones of the mafic rocks leading to a metasomatic alteration. Although, the mafic rocks have been altered and metasomatized by the granitic injection and have in turn contaminated the felsic material the actual compositional changes have in each case been small and rocks of the truly intermediate composition are formed and are usually the product of mechanical mixing of the felsic and mafic material.
Generally, the petrography of these rock samples reveal the presence of a mafic magma which has two pulses (a mafic and felsic pulse) of injection.

\section{ACKNOWLEDGEMENT}

T. Aga acknowledge the University of Jos for granting him study leave to enable him participate in the geological investigation of the Sar-Fier younger granite complex. The thin sections were prepared and studied at the Laboratory of the Department of Geology at the University of Jos, Jos, Nigeria.

\section{REFERENCES}

Aga, T. and A.I. Haruna, 2019a. The field geology and petrography of the Saiya-Shokobo Younger Granite Complex, Central Nigeria. Int. J. Geology Earth Sci., 5: 25-45.

Aga, T. and I.A. Haruna, 2019b. The geology and petrography of the Kofayi Younger Granite Complex, Central Nigeria. Int. J. Adv. Geosci., 3: 15-27.

Kinnaird, J.A., 1985. Hydrothermal alteration and mineralization of the alkaline anorogenic ring complexes of Nigeria. J. Afr. Earth Sci., 3: 229-251.

Macleod, W.N., D.C. Turner and E.P. Wright, 1971. The geology of Jos Plateau. Bull. Geol. Survey Nig., 1: 109-110.

Middlemost, E.A.K., 1985. Magmas and Magmatic Rocks. 1st Edn. An Introduction to Igneous Petrology, Longman Groupuk, London, ISBN: 0582300800, pp: 73-87.

Obaje, N.G., 2009. Geology and Mineral Resources of Nigeria. Springer, Berlin, Germany, ISBN-13: 9783540926849, Pages: 221.

Rahaman, M.A., 1988. Recent Advances in the Study of the Basement Complex of Nigeria. In: Precambrian Geology of Nigeria, Geological Survey of Nigeria, (Ed.). Geological Survey of Nigeria, Kaduna South, Nigeria, ISBN:9789783018709, pp: 11-43.

Turner, D.C., 1989. Structure and Petrology of the Younger Granite Ring Complexes. In: Geology of Nigeria, Kogbe, C.A. (Ed.). Rock View Ltd., Jos, Nigeria, pp: 175-190. 